\title{
Library performance measures
}

\author{
By Beverlee French \\ Head, Science and Engineering Library \\ University of California, San Diego
}

\section{Some recent research on quantifying performance.}

$\mathbf{R}$ ecognizing a need for analytical tools with which academic libraries can describe their activities quantitatively, the ACRL Board of Directors created the ad hoc Committee on Performance Measures in December 1984. Establishment of this Committee, chaired by Virginia Tiefel, was a major recommendation of the ACRL Task Force on Performance Measures. Part of the Committee's charge is to plan and advise the ACRL Board of Directors on developing and overseeing a contract for the publication of an initial set of performance measures for academic libraries. The Committee is also charged to identify and publicize existing tools for measuring library effectiveness that can be applied in academic libraries.

It is important to emphasize that "performance measures" are not academic library standards and they are not intended to provide comparative data; nor do they constitute a research methodology. Rather the Committee set out to select a set of quantitative measures related to commonly recurring goals in academic libraries that could constitute a manual. It was determined by the Committee that the measures would be decision-related, easy to apply and use, inexpensive to administer, and user-oriented. The measures will not necessarily fit together to form a comprehensive model of academic library effectiveness. Such a model would certainly be as complex as the array of objectives held by academic libraries and is probably beyond the reach of standardized approaches.

While there is a growing body of literature on evaluation of library performance, and a number of ALA divisions have focused on library effectiveness and performance measures, the Committee members continue to see a need for a practical manual of performance or output measures for academic and research libraries. In deliberating over the nature and contents of the proposed manual, the Committee examined several recent publications which meet many of the criteria outlined above and should be useful to academic librarians who would like to quantify the library user's experience.

Among these are:

Mary J. Cronin, Performance Measurement for Public Services in Academic and Research Libraries. Washington, D.C.: Office of Management Studies, Association of Research Libraries, 1985.

Paul B. Kantor, Objective Performance Measures for Academic and Research Libraries. Washington, D.C.: Association of Research Libraries, 1984.

Library Data Collection Handbook. Mary Jo Lynch, editor; Helen M. Eckard, project officer. Chicago: American Library Association, 1982.

Mary Kane Trochim, et al. Measuring the Circulation Use of a Small Academic Library Collection: A Manual. Washington, D.C.: Office of Management Studies, Association of Research Libraries, 1985.

Douglas Zweizig. Output Measures for Public Libraries: a Manual of Standardized Procedures. Chicago: American Library Association, 1982.

For an example of the application of the availability measures described in Kantor's manual, see "Book Availability at the University of California, Santa Cruz," by Terry Ellen Ferl and Margaret G. Robinson, College \& Research Libraries 47 (September 1986):501-8. Not only did these librarians 


\section{FOR ALL THOSE WHO MAKE KNOWLEDGE AN OPEN BOOK}
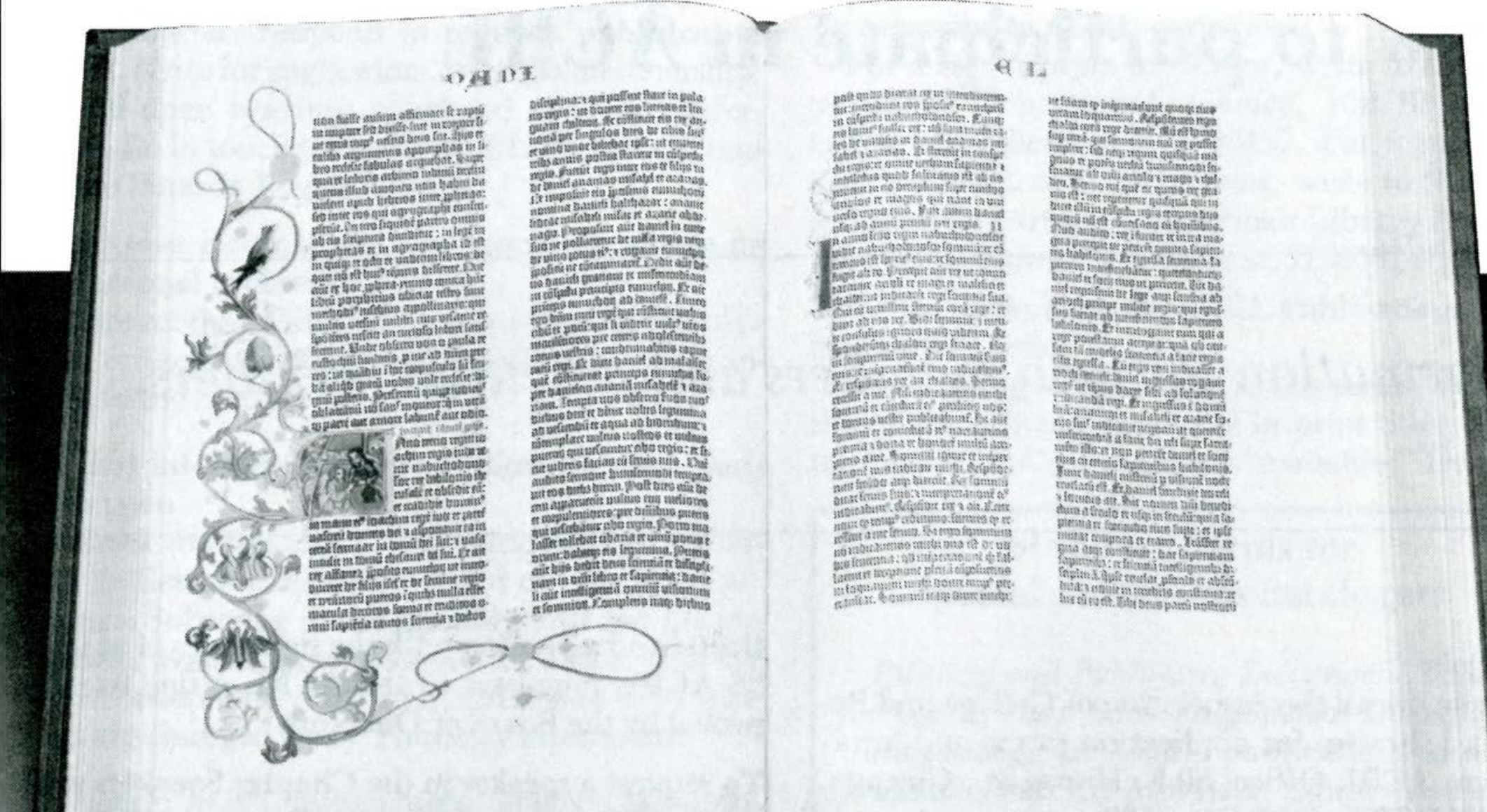

$\underline{1}$

No small credit for the modern day distribution of information goes to Mr. Gutenberg, a former goldsmith who created the first movable type... with inspiration and infinite attention to detail.

And no small credit goes to today's information manager, who provides access to the world's knowledge... with equal professionalism and craftsmanship.

When you spend your days making the world an open book, you expect support from professionals who are as meticulous as you are. EBSCO provides that support, with more than 165,000 titles on file-and professional staff providing responsive, personal service.

Count on EBSCO to respect the inspiration and attention to detail you require in subscription services. When it comes to serials, we're your open book.

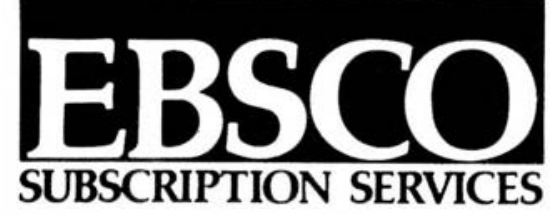


find through their investigations that widely held assumptions were unsubstantiated, but they look forward to results by comparable availability studies conducted at similar institutions. The validity, reliability, and sensitivity of the output measures for public libraries is examined in "Public Library
Effectiveness: Theory, Measures, and Determinants," by Nancy A. Van House, Library and Information Science Research 8 (1986):261-83. This paper confirms that while such measures are less than ideal research tools, they can be useful indicators for management decision making.

\section{How to participate in ACRL}

\section{Information for new members and potential members.}

$\mathbf{T}$

\section{o join}

Write or call the Association of College and Research Libraries for application forms and information: ACRL Office, 50 E. Huron St., Chicago, IL 60611-2795; (312) 944-6780.

To learn about ACRL's current programs, officers, and units

Check the ALA Handbook of Organization and read College \& Research Libraries News regularly (as a member of ACRL, you will receive both publications).

To attend conference programs, ACRL Board meetings, or committee meetings

For information on time, places, and general program content, consult $C \downarrow R L$ News, American Libraries, and the official conference programs and schedules. For additional information, contact the ACRL office.

\section{To attend preconferences}

For information about time, place, and preconference theme, check C $b R L$ News and American Libraries. For additional information and registration materials, write to the ACRL office.

To take a continuing education course

To receive a course brochure, write Sandy Donnelly at the ACRL office. To register, use information published in $C \& R L$ News or in the course brochure.

To establish a local chapter of ACRL

Check the procedures listed in "Guidelines for ACRL Chapters" (available from the ACRL of- fice). Send a petition with the signatures of at least 25 ACRL members to the ACRL office for approval by the Board of Directors.

To request a speaker in the Chapter Speakers program

Write Emma Miller at the ACRL office and specify your date and topic. Eight chapters qualify each year for a free visit from ACRL officers or the ACRL Executive Director.

To serve on ACRL's committees or to participate in ACRL's sections and discussion groups

Familiarize yourself with the work of the unitcheck the ALA Handbook of Organization for the unit's statement of responsibility, read about the work of the unit as reported in C $d R L N e w s$ and American Libraries, attend the meetings of the unit during ALA conferences. Submit a completed ACRL committee volunteer form (published in the October issue of $C \triangleleft R L N e w s$ and available at ALA conferences). Communicate your interest to the ACRL Appointments and Nominations Committee, to any of the ACRL officers, to the chair of an ACRL unit whose work interest you, or to the ACRL office.

To be a candidate for an ACRL office

Write to the ACRL Appointments and Nominations Committee or to an ACRL section nominating committee. Submit a petition to have your name added to the list of candidates.

To nominate someone for an award or to apply for a grant or fellowship

Write or call Mary Ellen Davis at the ACRL of- 